\title{
The Impact of Patient's Fear of COVID-19 Infection on Neurology Service in University Hospital Center Sestre Milosrdnice During COVID-19 Epidemic Outbreak
}

\author{
Arijana Lovrenčić-Huzjan ${ }^{1,2,3}$, Marina Roje-Bedeković1,2,4 \\ and Neurology Collaboration Group* \\ ${ }^{1}$ Department of Neurology, University Hospital Centre Sestre milosrdnice, Zagreb, \\ Croatia, ${ }^{2}$ School of Medicine, University of Zagreb, Zagreb, Croatia, ${ }^{3}$ School of Dental \\ Medicine, University of Zagreb, Zagreb, Croatia, ${ }^{4}$ School of Medicine, University of Split, \\ Split, Croatia
}

\begin{abstract}
Increasing evidence suggests that patients with medical emergencies are avoiding the emergency department because of fear of coronavirus disease 2019 (COVID-19) infection, leading to increased morbidity and mortality due to other diseases. In order to analyse the impact of patient's fear of COVID-19 on the admittance rate of stroke patients and severity of neurological diseases, we compared the stroke admittance rate, numbers of thrombectomies and thrombolysis and hospitalization refusal rate during the time period from March $1^{\text {st }}$ until June $30^{\text {th }} 2020$ in temporal relationship with the rising numbers of COVID-19 cases in Croatia. We assessed the patients' neurologic disease severity measured by ventilation time and mortality rate in the same time period. We compared the data with the data obtained from the same time period in 2019. We observed dramatically decreased presentation in Neurologic Emergency Department due to stroke and neurologic disease in 2020 compared to 2019, increased refused hospitalization rate and similar stroke treatment rate despite bigger catchment area. Greater neurologic disease severity with almost $40 \%$ increased ventilation time and double mortality rate during the same time was observed. During the outbreak of COVID-19 epidemic, fear of infection had significant impact on neurologic service leading to decreased presentation to NED, resulting in increased stroke or neurologic disease-related morbidity and mortality.
\end{abstract}

Key words: COVID-19; neurology; stroke; fear; thrombectomy; thrombolysis

Copyright @ 2021 KBCSM, Zagreb

e-mail: apr.kbcsm@gmail.com•www.http://apr.kbcsm.hr

\section{Introduction}

During the outbreak of coronavirus disease 2019 (COVID-19), the World Health

\section{Correspondence to:}

Arijana Lovrenčić-Huzjan, MD, PhD

Department of Neurology, University Hospital Centre Sestre

milosrdnice, Vinogradska 29 c., Zagreb, Croatia

Phone: +385 1 3787-740

E-mail: arijana.lovrencic.huzjan@kbcsm.hr
Organization recommended measures to mitigate the outbreak and reduce COVID-19 deaths, such as social distancing and confinement. However, after introduction of these measures, reports describe a dramatic decrease in the number of emergency department (ED) visits [1,2], alarming indicators of lengthened care delays [3] resulting in reduction of endovascular therapy (EVT) treatments for acute 
ischemic stroke due to large vessel occlusion, greater stroke-related morbidity and mortality [4-6], and increased emergency medicine service (EMS) reports of cardiac arrests [1]. These patients were declared dead and were not taken to emergency department. It was presumed that patients were waiting too long before seeking emergency care, and all tested negative for COVID-19.

Although the COVID-19 death rate seemed to be an accurate measure of the pandemic's worst outcome, it seems that pandemics effect other outcomes measured by greater disease severity, under-treatment or morbidity or mortality related to other diseases, have been underestimated in consequences of the pandemic [7]. Other diseases could claim lives indirectly through delayed care for other emergencies, exacerbations of chronic diseases, and psychological distress [7]. Therefore, the number of deaths attributed to COVID-19 in official reports is probably an underestimate of the deaths caused by COVID-19 pandemic, since statistics don't incorporate deaths indirectly attributable to the virus and the measured used to contain it [7].

After the Croatian Ministry of Health declared the COVID-19 epidemic in Croatia on March $11^{\text {th }} 2020$, the health system, healthcare professionals and resources were focused on the fight against COVID-19. Establishments were set up, such as respiratory centres and additional facilities for the care of patients with COVID-19 including Infectious Diseases Clinic "Dr Fran Mihaljević" and UH Dubrava in Zagreb. Other facilities were set up for the cares of patients with acute neurological diseases and conditions, such as stroke. In Zagreb, UHC Sestre Milosrdnice, and UHC Zagreb enables comprehensive stroke care, and therefore were set up for the care of acute neurological diseases and conditions, such as stroke. Patients with severe infections of the central nervous system or with other neurologic diseases, who were not cured during hospitalization before pandemic out- break and required further hospitalization from Infectious Disease Clinic or UH Dubrava were transferred to UHC Zagreb and UHC Sestre milosrdnice. Neurologic patients from previous catchment area of UH Dubrava were referred to UHC Zagreb and UHC Sestre Milosrdnice during the epidemic. These two centres also accepted patients for mechanical thrombectomy in "Drip and Ship" approach from other hospitals according to the stroke network

The aim of this report is to present the difference of the admittance/refusal rate of hospitalization for stroke and neurologic disease, thrombolysis and thrombectomy rate during time period from March $1^{\text {st }}$ until June $30^{\text {th }}$ 2020 in temporal relationship with the rising numbers of COVID-19 cases in Croatia, and in comparison, with the same calendar time period in 2019. We also compared the severity of neurologic diseases measured by length of ventilation time and mortality rate in the same calendar time period.

\section{Subjects and Methods}

Hospital information system was used to assess numbers of daily neurologic emergency visits between March $1^{\text {st }}$ and June $30^{\text {th }}$ 2020. Daily numbers of emergency admission to the Department of Neurology were counted. Daily refusals of emergency hospitalization for neurological emergent diagnosis were assessed. Data are presented in temporal relationship with the numbers of new COVID-19 cases in Croatia. Data are presented in comparison with the data during the same period in 2019.

Numbers of thrombolysis and thrombectomy cases were retrieved from the same time period, and expressed as cases per month during the same time period in 2020. Data were compared with the same period in 2019.

Neurologic disease severity was measured by total hours of ventilation time, which is recorded monthly in the intensive care unit and mortality rate, during the same time period in 2020, and compared with the same time period in 2019.

Data are presented as flow charts and tables. 
The study was approved by the Ethics Committee of UHC Sestre Milosrdnice.

\section{Results}

Croatia issued a nationwide shelter-inplace order on March $23^{\text {th }}, 2020$. The volume of patients presenting to the UHC Sestre milosrdnice neurologic emergency department (NED) dropped significantly after the shelter-in-place mandate (Figure 1, Figure 2). By the first week in April, volume dropped significantly.

Despite a bigger catchment area, the numbers of neurologic emergency admittance to Neurology Department were similar in March and April 2020 compared to the same months in 2019 (Figure 1). First, the decrease of number of stroke patients in March 2020 was observed, followed by slight increase during April 2020 (Table 1). The number of transient ischemic attacks (TIA) patients was lower dur-

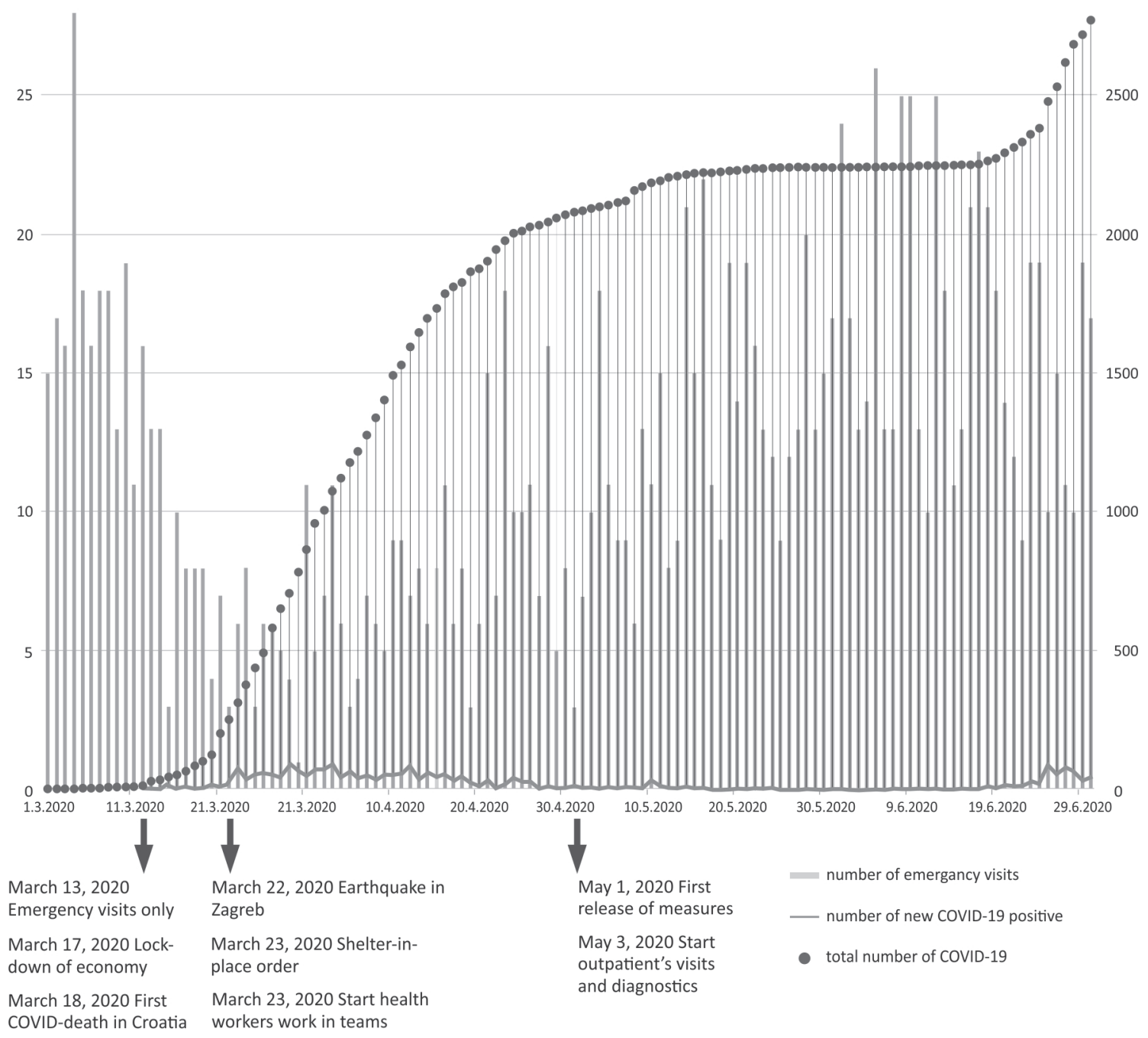

Figure 1. Neurologic Emergency Room volume by day and timeline of key events 


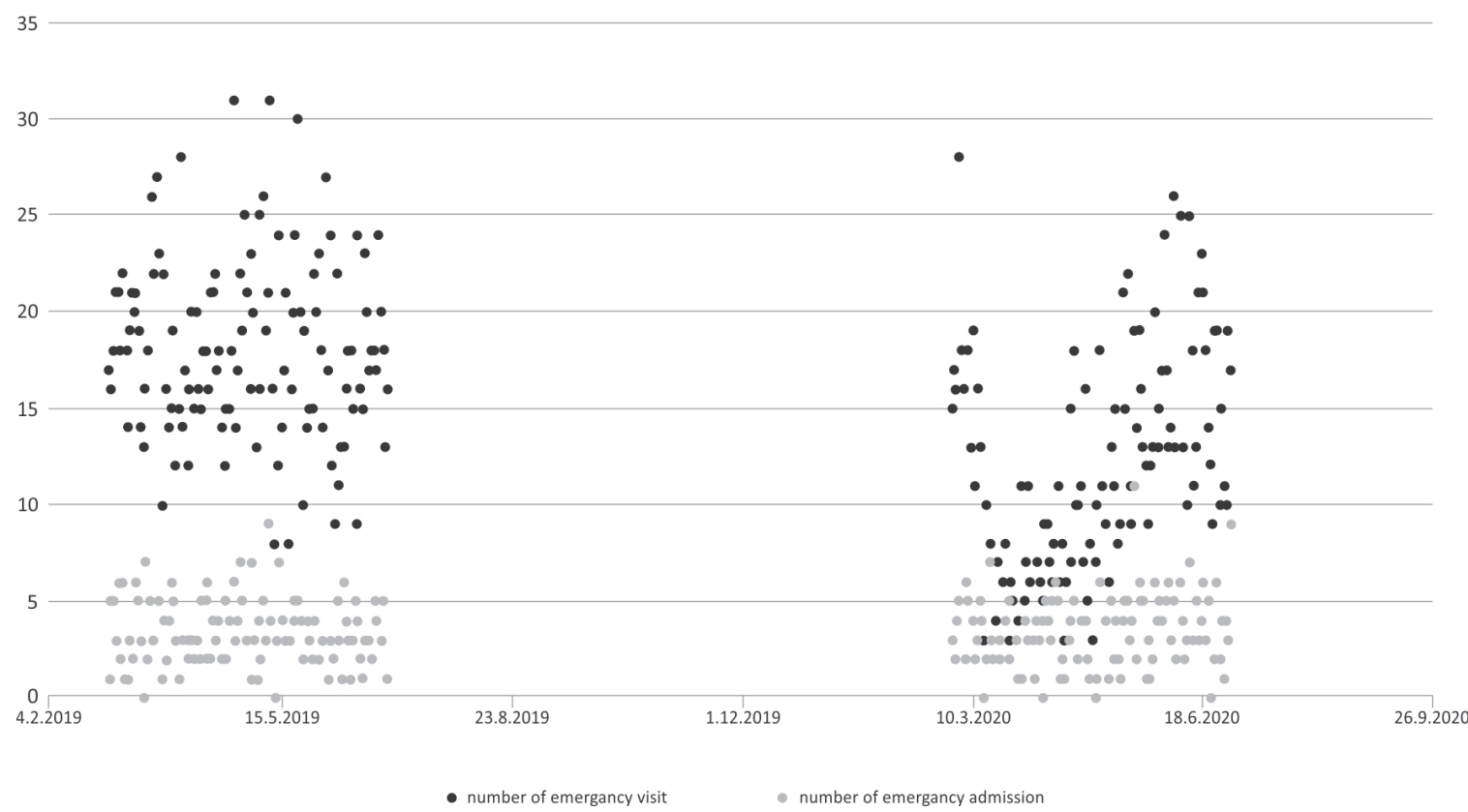

Figure 2. The comparison of Neurologic Emergency Room volume and admittance rate between year 2019 and 2020.

Table 1. The comparison of the presentation of stroke patients in Neurologic Emergency Room in year 2019 and 2020

\begin{tabular}{lcccccc}
\hline & $\begin{array}{c}\text { Ischemic } \\
\text { stroke }\end{array}$ & $\begin{array}{c}\text { Ischemic } \\
\text { stroke refused } \\
\text { hospitalization }\end{array}$ & $\begin{array}{c}\text { Transient } \\
\text { ischemic } \\
\text { attack (TIA) }\end{array}$ & $\begin{array}{c}\text { TIA refused } \\
\text { hospitalization }\end{array}$ & $\begin{array}{c}\text { Primary } \\
\text { intracerebral } \\
\text { haemorrhage }\end{array}$ & $\begin{array}{c}\text { Subarachnoid } \\
\text { haemorrhage }\end{array}$ \\
\hline March 2019 & 55 & 5 & N & N & N & N \\
March 2020 & 42 & 2 & 16 & 9 & 4 & 6 \\
April 2019 & 40 & 2 & 17 & 6 & 4 & 0 \\
April 2020 & 44 & 4 & 7 & 5 & 4 & 4 \\
May 2019 & 43 & 0 & 13 & 7 & 1 & 0 \\
May 2020 & 58 & 7 & 8 & 5 & 7 & 1 \\
June 2019 & 46 & 0 & 3 & 3 & 2 & 0 \\
June 2020 & 39 & 5 & 20 & 15 & 7 & 3 \\
\hline
\end{tabular}


Table 2. The comparison of the number of actively treated stroke patients between year 2019 and 2020

\begin{tabular}{lcccc}
\hline & \multicolumn{2}{c}{ Year 2019 } & \multicolumn{2}{c}{ Year 2020 } \\
\cline { 2 - 5 } Month & Thrombolysis & Thrombectomy & Thrombolysis & Thrombectomy \\
\hline March & $\mathrm{N}$ & $\mathrm{N}$ & $\mathrm{N}$ & $\mathrm{N}$ \\
April & 3 & 13 & 1 & 17 \\
May & 3 & 12 & 4 & 17 \\
June & 3 & 11 & 3 & 15 \\
Total & 4 & 53 & 13 & 58 \\
\hline
\end{tabular}

ing March, April and May in 2020 compared to the same months in 2019 (Table 1). The number of stroke patients further and significantly increased in May 2020 compared to previous months and compared to the same time period in 2019. However, the number of TIA patients started to increase in June 2020, but with increased refusal to hospitalization. More patients with primary intracerebral haemorrhage in year 2020 compared to the previous year were observed, especially in May and June 2020. No patient presented with subarachnoid haemorrhage during March, April and May 2020 and 2 during June 2020. During same period in the previous year, 14 patients were treated.

Despite a bigger catchment area in 2020, a similar number of treated stroke patients was observed (Table 2) in 2020 compared to 2019.

Increased neurologic disease severity, estimated by length of ventilation time in year 2020 compared to the same calendar time in 2019, was observed (Table 3). Also, an increased number of deaths were observed in 2020 compared to the same time period in 2019 (Table 3).

Table 3. The comparison of neurologic disease severity estimated by ventilation time and deaths between year 2019 and 2020.

\begin{tabular}{lcccc}
\hline & \multicolumn{2}{c}{ Year 2019 } & \multicolumn{2}{c}{ Year 2020 } \\
\cline { 2 - 5 } Month & $\begin{array}{c}\text { Ventilation time } \\
\text { (hours) }\end{array}$ & $\begin{array}{c}\text { Deaths } \\
\text { Ventilation time } \\
\text { (hours) }\end{array}$ & $\begin{array}{c}\text { Deaths } \\
\text { N }\end{array}$ \\
\hline March & 1200 & 3 & 1067 & 12 \\
April & 1199 & 4 & 2577 & 10 \\
May & 1226 & 8 & 784 & 13 \\
June & 1275 & 5 & 2311 & 9 \\
Total & 4900 & 20 & 6739 & 44 \\
\hline
\end{tabular}




\section{Discussion}

Despite a bigger catchment area during the COVID-19 outbreak, amid the first two months of the outbreak a decreased number of patients presented to NED UHC Sestre Milosrdnice was observed in comparison to the same calendar time period in year 2019. During March 2020, a dramatic drop of ischemic stroke, TIA and patients with subarachnoid haemorrhage was observed. Most TIA patients in March, April and May 2020 refused hospitalization compared to the same period in 2019. Also, higher rates of refusal of hospitalization of stroke patients during April, May and June 2020 was observed compared to the same months in 2019. We presumed that the reason was fear of being infected with COVID-19, due to "Emergency visits only" and "Stay at home" orders had been declared. Because significantly increased number of patients with primary intracerebral haemorrhage, who usually have a more severe clinical picture, during all four observed months was observed compared to the previous year, we presume that even more stroke patients with milder strokes stayed at home. In support of this speaks a dramatic drop of patients with subarachnoid haemorrhages, since no patients with subarachnoid haemorrhage have presented to emergency room neither were referred from other facilities during March, April and May 2020. We presume that patients with milder or isolate subarachnoid symptoms, like headache only, were not recognized by patients or family doctors and therefore have stayed at home. May happen also, that re-rupture of aneurysm was fatal, since we didn't observe any of these patients in NED. Usually, patients with subarachnoid haemorrhage represent only minor percentage of stroke patients (about 5\%), but it's unusual that no patient was observed during three months despite larger catchment area and increased number of patients with intracerebral haemorrhage. Patients with primary intracerebral haemorrhage and severe clinical picture were referred to NED, therefore these numbers may serve as a marker of increased number of stroke patient volume corresponding to increased catchment area that would normally be referred and admitted to Neurology clinic. Therefore, we can also presume that more ischemic stroke patients should have presented to NED, and should receive treatment. We have no data of those patients that denied referral to hospital and died at home.

A similar dramatic decrease in presentation of stroke and other acute cardiovascular patients to emergency departments (ED) was observed around the world amid COVID-19 outbreak [9]. Like in stroke patients, it was found that large numbers of patients with acute myocardial infarction initially avoided hospitalization during the COVID-19 pandemic, likely out of fear of contracting SARSCoV-2 [9]. At the same time, large increases in mortality from heart disease $(89 \%)$, diabetes $(96 \%)$, Alzheimer disease (64\%), and cerebrovascular diseases (35\%) were observed [8]. Emergency medical service (EMS) reported more cardiac arrests [1], and most of them were declared dead and not taken to ED's [1]. Also, it was observed that most stroke patients who arrived to hospitals, arrived too late to receive active treatment like thrombolysis or thrombectomy $[1,3,4,6]$. However, we haven't observed decrease in number of stroke treatment in 2020 compared to 2019, even more thrombectomy cases were observed in 2020 compared to 2019. Therefore, our patients haven't received worse treatment due to inhospital stroke service. We can only presume that more stroke patients should be referred to hospital, and that only more severe cases have been presented and received treatment. Therefore, the outcome is only the reflection of more severe cases referred, admitted and treated in the Neurology Department during the outbreak of the pandemic. In favour of this speaks a dramatically decreased volume of 
NED visits and $50 \%$ increased number of patients with primary intracerebral haemorrhage in 2020 compared to 2019.

In most stroke centres, worse stroke outcome was reported $[4,6]$. In a New York study, among COVID-19 patients who suffered stroke, the rate of cryptogenic and embolic strokes was higher than what is usually seen [10]. The New York study also showed that strokes in COVID-19 patients were more severe, the death rate was higher, and patients were younger than strokes that were not associated with COVID-19 [10]. Only one study in Denmark showed that patients did not present with more severe strokes, nor did the reorganization of healthcare systems, which may have influenced in hospital treatment delay, have an impact on very short-term mortality [11]. This study also showed that mortality among patients admitted with stroke in Denmark, overall and according to subtypes, was not significantly higher following lockdown compared with the preceding years [11].

After initial dramatic decreased hospitalization rate of stroke and acute neurologic disease, after relaxation of measures in May 2020, we observed an increase in hospitalization rates and increase in stroke treatment. Similar data were observed in myocardial infarction service, where at the beginning of increase in hospitalization rates for acute myocardial infarction was observed, but also did the risk of in-hospital mortality [9] We also observed increased stroke severity measured by increase in mechanical ventilation time and increased mortality rates. More severe cases were observed during the pandemic, therefore ventilation time during observed four months increased for almost $40 \%$ and mortality rates doubled. Therefore, we presume that milder cases of emergency neurologic patients were not referred to, or presented to NED, and only more severe cases were admitted to Department of Neurology. Therefore, in hospital mortality rates were increased. We do not have the data of mortality of patients who stayed at home.

Although COVID-19 death rate is reported to be an accurate measure of the pandemic's worst outcome, it seems that the effect of the pandemic on other disease outcomes, measured by greater disease severity, under treatment or morbidity or mortality related to these other diseases, have been underestimated in studies that should report the overall consequences of pandemic $[7,8]$.

Huge collateral damage due to public fear of contracting COVID-19 infection, to acute neurologic and stroke patients was present during the COVID-19 pandemic outbreak. We presume that patients with milder clinical picture decided not to contact the medical service, or were not recognized as stroke patients and not referred to hospital, or that have even died at home and not being recognized. We had fewer emergency treatments due to lack of arrival to hospital admissions or refusal to hospitalization. We also observed greater neurologic disease severity. Greater disease severity and worse outcomes contribute to unmeasurable morbidity and mortality that is routinely expressed as an outcome of pandemic. Preparedness and innovation in health care delivery should be applied amid outbreaks in the future.

\section{Acknowledgements}

The authors acknowledge the Croatian Institute for Public Health for providing data on the daily number of newly infected persons during the outbreak of the COVID-19 epidemic.

\section{Conflict of Interest}

Arijana Lovrenčić-Huzjan is president of the Ethics Committee of UHC Sestre milosrdnice. Due to the conflict of interest, she did not participate in the discussion or deci- 
sion-making on the proposed research. The authors declared no potential conflicts of in- terest with respect to the research, authorship, and/or publication of this article.

\section{References}

1. Wong LE, Hawkins JE, Langness S, Murrell KL, Iris P, Sammann A. Where are all the patients? Addressing Covid-19 fear to encourage sick patients to seek emergency care. N Engl J Med Catalyst [Internet]. 2020 [cited 2021 Jan 7]. Available from: https://catalyst.nejm.org/.

2. Morelli N, Rota E, Terracciano C, Immovilli P, Spallazzi $\mathrm{M}$ Colombi D, et al. The baffling case of ischemic stroke disappearance from the casualty department in the COVID-19 era. Eur Neurol. 2020;83:213-5.

3. Kerleroux B, Fabacher T, Bricout N, Moïse M, Testud $\mathrm{B}$, Vingadassalom S, et al. On behalf of the SFNR, the ETIS registry, and the JENI-Research Collaborative. Mechanical thrombectomy for acute ischemic stroke amid the COVID-19 outbreak. Decreased activity, and increased care delays. Stroke. 2020;51:2012-7.

4. Hajdu SD, Pittet V, Puccinelli F, Hassen WB, Ben Maacha MB, Blanc R, et al. Acute stroke management during the COVID-19 pandemic. Does confinement impact eligibility for endovascular therapy? Stroke. 2020;51:25936.

5. Kansagra AP, Goyal MS, Hamilton S, Albers GW. Collateral effect of Covid-19 on stroke evaluation in the United States. N Engl J Med. 2020;383:400-401.

6. Montaner J, Barragán-Prieto A, Pérez-Sánchez S, Escudero-Martínez I, Moniche F, Sánchez-Miura JA, et al. A. Break in the stroke chain of survival due to COVID-19. Stroke. 2020;51:2307-14.

7. Zylke JW, Bauchner H. Mortality and morbidity. The measure of a pandemic. JAMA. 2020;324:458-9.

8. Woolf SH, Chapman DA, Sabo RT, Weinberger DM, Hill L. Excess deaths from COVID-19 and other causes, March-April 2020. JAMA. 2020;324:510-3.

9. Gluckman TJ, Wilson MA, Chiu S-T, Penny BW, Chepuri WB, Waggoner JW, et al. Case rates, treatment approaches, and outcomes in acute myocardial infarction during the coronavirus disease 2019 pandemic. JAMA Cardiol. 2020;5:1-6.

10. Yaghi S, Ishida K, Torres J, Grory MB, Raz E, Humbert $\mathrm{K}$, et al. SARS-CoV-2 and stroke in a New York healthcare system. Stroke. 2020;51:2002-11.

11. Butt JH, Fosbøl EL, Østergaard L, Yafasova A, Andersson C, Schou M, et al. Effect of COVID-19 on firsttime acute stroke and transient ischemic attack admission rates and prognosis in Denmark: A nationwide cohort study. Circulation. 2020;142:1227-9.

*Neurology Collaboration Group: Melanija Barbir ${ }^{1}$, Vanja Bašić Kes ${ }^{1}$, Marijana Bosnar Puretić ${ }^{1}$, Breitenfeld Tomislav ${ }^{1}$, Mislav Budišićc ${ }^{1}$, Lejla Črić ${ }^{1}$, Branimir Čulo ${ }^{5}$, Lidija Dežmalj Grbelja ${ }^{1}$, Ana Dimitrović ${ }^{1}$, Sara Drnasin ${ }^{1}$, Nevena Grbić $^{1}$, Marija Ivica ${ }^{1}$, Miljenka-Jelena Jurašić ${ }^{1}$, Vladimir Kalousek ${ }^{5}$, Ivana Kobasić ${ }^{1}$, Marijana Lisak ${ }^{1}$, Ivan Malek ${ }^{6}$, Irena Martinić Popović ${ }^{1}$, Valentina Miler ${ }^{7}$, Marta Polegubić ${ }^{1}$, Ivan Stojić ${ }^{1}$, Višnja Supanc ${ }^{1}$, Zlatko Trkanjec ${ }^{1}$, Helena Trputac ${ }^{1}$, Ivana Vinski $^{1}$, Rafaela Vukasović ${ }^{1}$, Lucija Zadro Matovina ${ }^{1}$

${ }^{1}$ Department of Neurology, University Hospital Centre Sestre milosrdnice, Zagreb, Croatia, ${ }^{5}$ Department of Diagnostic and Interventional Radiology, University Hospital Centre Sestre milosrdnice, Zagreb, Croatia, ${ }^{6}$ General County Hospital Čakovec, Čakovec, Croatia, ${ }^{7}$ General Hospital Virovitica, Virovitica, Croatia 


\section{Utjecaj straha bolesnika od infekcije COVID-19 na neurološku službu u Kliničkom bolničkom centru Sestre Milosrdnice tijekom izbijanja epidemije COVID -19}

Sažetak - Sve je više dokaza koji upućuje na to da bolesnici s hitnim medicinskim stanjima izbjegavaju hitnu službu zbog straha od infekcije koronavirusom 2019 (COVID-19), što dovodi do povećanog morbiditeta i smrtnosti od drugih bolesti. Kako bismo analizirali utjecaj straha bolesnika od infekcije COVID-19 na stopu prihvata bolesnika s moždanim udarom i težinu neuroloških bolesti, uspoređivali smo stopu prihvata za moždani udar, broj trombektomija i trombolize i stopu odbijanja hospitalizacije tijekom razdoblja od 1. ožujka. do 30. lipnja 2020. u vremenskom odnosu s rastućim brojem slučajeva COVID-19 u Hrvatskoj. Procijenili smo težinu neuroloških bolesti mjerom vremena mehaničke ventilacije i stopom smrtnosti u istom razdoblju. Usporedili smo podatke s podacima dobivenim iz istog kalendarskog vremenskog razdoblja u 2019. godini. Primijetili smo dramatično smanjenje broja pregleda u Hitnoj neurološkoj ambulanti zbog moždanog udara i neuroloških bolesti 2020. godine u odnosu na 2019. godinu, povećanu stopu odbijene hospitalizacije i sličnu stopu liječenja moždanog udara usprkos većem pripadajućem teritoriju. Uočili smo veću težinu neuroloških bolesnika mjerenu gotovo $40 \%$ povećanim vremenom mehaničke ventilacije i udvostručenom stopom smrtnosti u istom vremenskom razdoblju. Tijekom izbijanja epidemije COVID-19, strah od infekcije imao je značajan utjecaj na neurološku službu, što je dovelo do smanjene prezentacije neuroloških bolesnika u neurološkoj hitnoj službi, a rezultiralo je povećanim morbiditetom i smrtnošću zbog moždanog udara ili drugih neuroloških bolesti

Ključne riječi: COVID-19; neurologija; moždani udar; strah; trombektomija; tromboliza 
